\title{
Sandelian Antiliberalism
}

\author{
Michael S. Moore甲
}

Professor Sandel's paper continues the critique of liberalism begun by him in his earlier work, ${ }^{1}$ and so it is helpful to read this paper in hight of that work. In presenting such a reading here, I shall seek to do four things: (1) clarify what the question is to which Sandel's "antiliberalism" should be the answer; (2) restate Sandel's taxonomy of possible answers to the question as I have clarified it; (3) restate Sandel's particular objections to liberalism in a way that displays their general form; and (4) explain what liberalism can be even if Sandel's rejection of what he calls liberalism were accepted. I undertake these largely exegetical tasks in this Comment because I believe Professor Sandel has lost the forest for the trees in his present paper, focused as it is on a detailed explication of Supreme Court privacy cases.

\section{I \\ What Is The Question?}

The bulk of Sandel's discussion traces the development of Supreme Court doctrine on the right of privacy. This, it seems to me, is bound to miss the question of political theory at which this symposium is aimed. True enough, the impetus for such a symposium most immediately comes from decisions like Bowers v. Hardwick ${ }^{2}$ and Roe v. Wade. ${ }^{3}$ Yet our question is not a question of constitutional law, but a prior question of political theory.

To see this, let us begin where Sandel begins, with the Supreme Court's "old privacy" doctrine. Sandel accurately notes that "new privacy" protects decisional freedom, not freedom from access, from attention by others, and from others' possessing information about one, the

$\dagger$ Professor of Law, Boalt Hall School of Law, University of California, Berkeley; Robert Kingsley Professor of Law, University of Southern California; Resident Fellow, Humanities Research Institute, University of California, Irvine.

1. M. SANDEL, LiberalisM AND THE Limits OF JUSTICE (1982) [hereinafter LibERALISM]; Sandel, The Procedural Republic and the Unencumbered Self, 12 POL. THEORY 81 (1984) [hereinafter Procedural Republic]; Sandel, Introduction to LIBERALISM AND ITS CRITICs (M. Sandel ed. 1984) [hereinafter Introduction].

2. 476 U.S. 186 (1986).

3. 410 U.S. 113 (1973). 
true essence of privacy. ${ }^{4}$ As many others have noted, "privacy" is the wrong label for the constitutional right at issue in cases like Bowers and Roe. "Liberty" is the correct name, for what is at stake in such cases is the individual's right to be free from government regulation of fundamental decisions. Once we see that "privacy" is a bad label for the constitutional right to liberty, we are a step closer to seeing what our question is.

The correlative of a constitutional right to liberty on the part of citizens is a constitutional duty of legislatures not to regulate citizen behavior for no good reason. The concept that is "wearing the trousers"6 here is that of legislative duty, not that of citizen right. A general right to liberty is contentless until one spells out what justifications a legislature may and may not use to regulate citizens' choices. ${ }^{7}$ As Justice Brennan described the right: "If the right of privacy means anything, it is the right of the individual . . . to be free from unwarranted governmental intrusion . ..." It is unwarranted or unjustified legislative action that violates the relevant legislative duty here, and it is the specification of just what legislative action qualifies as unjustified that gives content to any general right to liberty on the part of citizens.

To reach our question we must thirdly shift the point of view from which the question of legislative duty is asked: ask this question from the point of view of a legislator, not from the point of view of a court reviewing that legislator's work. Every conscientious legislator should have a theory of her role as a legislator. Such a theory should include a theory about the principled limits of legislation; What ends are proper ends to seek via legislation? ${ }^{9}$ This question of proper legislative role is a question of political theory, not of constitutional law; for neither the political theorist nor the legislator who asks this question cares a fig about proper court functions-the problems of judicial review and judicial restraint. These latter, court-centered questions are central to constitutional law, ${ }^{10}$

4. The nature of privacy is explored by Ruth Gavison along these lines in Gavison, Privacy and the Limits of Law, 89 YALE L.J. 421 (1980).

5. Even Robert Bork. Bork, The Supreme Court Needs a New Philosophy, FortunE, December 1968, at 138, 170.

6. This is J.L. Austin's nice phrase for that member of a pair of terms whose meaning guides the meaning of the other member of the pair. Austin's example is voluntary and involuntary, where conditions of excuse (involuntariness) determine by exclusion what is voluntary. Austin, $A$ Plea for Excuses, 57 Proc. ARIST. SOC'Y 1 (1956).

7. This is why there is such a debate about whether there is a general right to liberty (as opposed to rights to more specific liberties). See J. Raz, The Morality of Freedom 6-8 (1986).

8. Eisenstadt v. Baird, 405 U.S. 438, 453 (1972) (emphasis added and deleted).

9. I defend this view about the office of legislator in my 1984 Asia Foundation Lectures on Legislation, given to Seoul National University and the Legislative and Administrative Agency of the Republic of Korea. See particularly The Limits of Legislation, in USC CITES 23 (Fall-Winter, 1984).

10. I explore these jurisprudential and constitutional questions with particular respect to the 
but are irrelevant to the political theory question of proper legislative role.

I take this symposium's focus to be the question that Bentham, Mill, and Stephens ${ }^{11}$ debated in the nineteenth century in England: Are there any principles of pohtical morality that limit the aims with which legislation nuay be inotivated, and if so, what are those limiting principles? To this question of pohitical theory, discussion of Supreme Court doctrineparticularly doctrine that is doubly miscast as being about citizen's rights, rather than legislative duty, and about a right to privacy rather than a right to liberty-is a distraction.

Of course, it is possible that doctrines of constitutional law adopt without change one or another political theory about proper legislative role. Yet considerations of proper court function nuay well prevent such wholesale adoption or, more likely, so warp the political theory in the process of its rebirth as constitutional doctrine that it becoines unrecognizable. In any case, the prior question is that of political theory: Are there any principled limits to proper legislative aims, and if so, what are they?

\section{II}

\section{What Are The Possible Answers?}

There are doubtlessly many ways of taxonomizing possible answers to my general question of political theory. Yet our concern is not to articulate a full theory of legislative role, but just so much of it as is needed to answer the subquestion that fascinated Mill: May a legislator aim in his legislation to further his own best judgments about the morality of practices like abortion and homosexuality? There are two answers to Mill's question: "yes" and "no." Sandel calls the "yes" answer the "naive" view, the "no" answer the "sophisticated" view. ${ }^{12}$ The naive view holds that a legislator may (and perhaps should) use his own best judgment about the morality of homosexuality and abortion in framing laws regulating those practices. If such a legislator believes that hoinosexuality is immoral, but that abortion is noral, these beliefs count as proper reasons with which to motivate legislation banning homosexual

privacy cases in Moore, The Written Constitution and Interpretivism, 12 HaRv. J. L. \& PuB. PoL. 3 (1989); Moore, The Constitution as Hard Law, 6 CoNST. CoMM. 51 (1989); and Moore, Do We Have an Unwritten Constitution?, 63 S. CAL. L. REV. (forthcoming 1989).

11. J. Bentham, AN Introduction To the PRINCIPLes of Morals and Legislation (1823); J.S. MILL, ON LIBERTY (1859); J.F. STEPHENS, LIBERTY, EQUALITY, FRATERNITY (1873). For modern discussions of this debate, see P. Devlin, The Enforcement of Morals (1965); T. Grey, The Legal ENforcement of Morality (1983); H.L.A. Hart, Law, Liberty, and MORALITY (1963); MORALITY AND THE LAW (R. Wasserstrom ed. 1971).

12. Sandel, Moral Argument and Liberal Toleration: Abortion and Homosexuality, 77 CAL1F. L. REV. 521, 521 (1989) [hereinafter Moral Argument ]. 
behavior but permitting abortions. The usual name for this kind of theory of legislation is legal morahism. ${ }^{13}$

The naive view is not hostage to any particular type of moral theory. A naive legislator may be a consequentialist, holding that right action is always a function of maximizing good states of affairs. ${ }^{14}$ Such a naive, consequentiahist legislator may hold a welfare-based theory of the good, identifying good states of affairs with pleasure, happiness, or preferencesatisfactions, in which event he will be a utilitarian; or he may be a nonutilitarian, holding that what makes states of affairs good includes nonwelfare-based items like virtues being realized, duties being done, equal distributions being achieved, and rights not being violated. ${ }^{15}$

Alternatively, a naive legislator may be a nonconsequentialist in his moral theory, holding the rightness of actions to be independent of the goodness of the states of affairs those actions produce. On this view, morality consists of absolute norms that forbid actions violating them no matter how good the consequences. ${ }^{16}$

Throughout his paper and his earlier work, Sandel unwarrantedly links the naive view of legislative role to consequentiahist morality of a certaim type (what Sandel calls the "teleological" view of morality). Sandel thinks that whenever a legislator "grounds the right of privacy on the good of the practice it would protect"17 (that is, whenever he is a consequentiahist who views rights as only an instrumental means to the reakzation of other goods), that legislator has adopted the naive view. By contrast, Sandel believes that whenever a legislator adopts the "claim that the right is prior to the good"-meaning by this "that individual rights cannot be sacrificed for the sake of the general good" and "that the principles of justice that specify these rights cannot be premised on any particular vision of the good life"-that legislator has adopted the sophisticated view. ${ }^{18}$

Neither of these connections holds at all. The morality that the naive legislator may think proper to consult when he legislates may be of any type whatsoever. Sandel has simply confused a question of political theory-when may legislation seek to promote some moral view-with a question of metaethics-what is the relation between the goodness of

13. See sources cited supra note 10; see also J. FEINBERG, HARM to OTHERS 12-13 (1984).

14. On consequentialism generally, see S. SCHEFfleR, THE Rejection of CONSEQUENTIALISM (1982).

15. For examples of nonutilitarian consequentialisms and theories, see Scanlon, Rights, Goals, and Fairness, and Sen, Rights and Agency, both in CONSEQUENTIALISM AND ITS CRITICS (S. Scheffler ed. 1988).

16. I defend a complex, agent-relative view of morality in Moore, Torture and the Balance of Evils, 23 ISRAEL L. REV. (forthcoming 1989).

17. Moral Argument, supra note 12, at 535-36.

18. Procedural Republic, supra note 1, at 82. See also LiBERALISM, supra note 1, at 9. 
certain states of affairs and the rightness of behavior tending to proinote them? There is simply no relation between these questions, so that the naive (or legal inoralist) legislator could seek to incorporate bibertarianism, egalitarianisın, utilitariamism, or any other moral view in his legislation.

The sophisticated legislator, by contrast, does not have to face a choice of moral theories, for what nakes him sophisticated is his refusal to embed his own inoral view of practices like homosexuality and abortion in legislation regulatimg such practices. Sandel recognizes two kinds of sophisticated legislator: the inajoritarian and the liberal. The inajoritarian does not seek to pass judgment on the inorality of abortion, hoinosexuality, etc., but rather legislates on sucl issues on the basis of what a majority in his society judge to be the morabity of such practices. The biberal beheves that "the state should not impose a preferred way of life, but should leave its citizens as free as possible to choose their own values and ends, consistent witli a similar hiberty for others." 19 Both the inajoritarian and the liberal distance themselves from their own critical moral judgments when they legislate-that's what inakes them "sophisticated"- -but they do so for different reasons. The inajoritarian allows the inajority's moral views to operate as a reason justifying legislation; the liberal allows eacli individual's moral views to govern his own behavior and legislates so as to provide a fair framework for each individual to work out just what those inoral views are.

Although Sandel does not explain it, the majoritarian might be led to his sophisticated view of legislative role by any of a number of routes: Democracy is good, and democracy works best when each lawmaker simply passes along the moral views of a majority of his constituents rather than basing legislation on his own inoral view; utility is good, and utility is enhanced when the preferences of a majority in society (that certain practices do or do not take place) are satisfied by legislation that regulates beliavior to conform to those preferences; community is good, and commumity is enhanced when the divergent practices of the minority are stamped out (or at least kept out of sight) by law; or, the ouly thing that can sensibly be said to be good is what the majority prefers, for inorality is nothing other than majority preference.

Sandel does mention four routes by which the liberal might be led to this sophisticated view of legislative role: ${ }^{20}$ (1) The voluntarist view, which holds that it is intrimsically right that each choose her own plan of life to the greatest extent possible, given everyone else's similar opportunity for choice; (2) the minimalist or pragmatic view, which accords a right to choose life-plans an instrumental status, sucl right being a

19. Introduction, supra note 1 , at 1 .

20. Moral Argument, supra note 12, at 522. 
means to further social cooperation and harmony; (3) the utilitarian view, which in the hands of Mill and subsequent rule-utilitarians also accords the right to choose life-plans an instrumental value, such a right being a means to the greatest happiness in the long run; and (4) the relativist view, which grants each such a "right" by default-that is, values being relative, no one can judge life-plans anyway, so one should not by legislation prefer one life-plan over another.

\section{III}

\section{SANDEL's ReJection OF THE SoPHISTICATEd View OF LEgISLATIVE ROLE}

Sandel's thesis is one with which I have considerable sympathy. It is that there is some "truth in the naive view .... The justice (or injustice) of laws against abortion and homosexual sodomy depends, at least in part, on the morality (or immorality) of those practices."21 The proper legislator, in other words, cannot legislate about such practices without himself developing a moral view about such practices and treating that view as a reason for legislating one way or the other.

Sandel defends this thesis by attacking directly only two of the four kinds of liberal sophistication: voluntarist and minimalist liberalism. Sandel in this paper ignores majoritarian sophistication altogether. Sandel has earlier dispatched the utilitarian basis for liberalism on the familiar (and correct) ground that utilitarianism is incapable of justifying the limited legislative role Mill described with his right to liberty because utilitarian calculations will not always coincide with what such a limited role demands. ${ }^{22}$ Sandel also dismisses relativist liberalism in a similar manner; it is paradoxical, he argues, to hold that all values are relative and to hold that liberty is good. As Sandel accurately concludes, "The relativist defense of liberalism is no defense at all."23 By process of elimination Sandel thus reaches his target, the kinds of liberalism he attributes to Kant and Dworkin (voluntarism) and to Rawls (minimalism).

Sandel's arguments against voluntarist and minimalist liberalism seem very thin, even to one such as myself who is sympathetic to their conclusion. In his present paper Sandel presents only two arguments, which he uses against both voluntarist and minimalist liberalism. The first is what I shall call the argument from nonneutral derivation. As Sandel puts it, "the case for bracketing a particular moral or religious controversy may partly depend on an implicit answer to the controversy it purports to bracket." 24 Put in my language: any lawmaker must justify

\footnotetext{
21. Id. at 521 .

22. Introduction, supra note 1 , at 2-3.

23. Id. at 1 .

24. Moral Argument, supra note 12, at 531.
} 
why it is right for him not to base legislation about abortion on a moral view about abortion; such justification will itself involve the lawmaker in appealing to some moral view and that moral view will include some judgment about the morality of abortion.

This kind of argument is a familiar one in legal philosophy. Against purportedly value-free theories of adjudication, for example, it is often urged that any judge must justify why it is right for him not to base his decision on some moral view of the merits of the controversy before him. Such justification will itself involve the judge im appealing to some moral view, and that moral view will have to take into account the very values it purportedly justifies excluding. ${ }^{25}$

I myself have used some such arguments to argue for the impossibility of value-free adjudication, either in common law or statutory reasoning. ${ }^{26}$ But Sandel gives us no reason to think that such an argument can succeed in political theory. His fleshing out of the argument against minimalist liberalism consists of a single example: One who seeks to "bracket" the controversy over the morality of abortion by letting the woman decide for herself cannot avoid a substantive position on the moral merits of that controversy, namely, a position on when life begins. ${ }^{27}$ Yet without saying so, Sandel in this example assumes that minimalist liberalism is committed to something like Mill's harm principle, so that no harm to another person is a precondition of bracketing. I don't see liberalism so confined. A legislator might well justify the woman's right to choose for herself (and thus bracket the issue for himself) even though he concedes the fetus is a person harmed by her decision. Indeed, Judy Thomson famously constructed a view of this particular right having no "no harm" justification for its existence. ${ }^{28}$

Sandel's fleshing out of the argument as it applies to voluntarist liberalism is no more successful. Sandel argues that "the voluntarist justification of privacy rights is dependent-politically as well as philosophically-on some measure of agreement that the practices protected are morally permissible." 29 What Sandel seems to mean here is that you get social cooperation and peace on issues like homosexuality only if people share a view on the moral merits of homosexuality-for example, the view that it is not immoral. Sharing only the view that each person has a right to do what she wants with her body is not enough for such cooperation and peace.

25. E.g., R. DWORKIN, TAKING Rights SERIOUSLY 37-38, 48-58, 105-15 (1978).

26. Moore, A Natural Law Theory of Interpretation, 58 S. CAL. L. Rev. 277 (1985); Moore, Precedent, Induction, and Ethical Generalization, in PrECEDENT IN LAw 153 (L. Goldstein ed. 1987).

27. Moral Argument, supra note 12, at 531-532.

28. J. Thomson, $A$ Defense of Abortion, in Rights, Restrtution, ANd Risk 1 (1986).

29. Moral Argument, supra note 12, at 537. 
There are two things wrong with this argument: It is irrelevant and it is false. The irrelevance point first. This is supposed to be an argument against voluntarist liberalism. The voluntarist, as Sandel has defined him, attaches intrinsic importance to moral rights such as the right to do with one's body sexually what one will. So of what relevance is it to the voluntarist justification of bracketing the moral issue of homosexuality that social cooperation will not be achieved? Social cooperation for the voluntarist is not the end that justifies granting each of us the legal right to choose; unlike the minimalist, the voluntarist justifies such legal rights by the moral rights of the same content that we each possess.

Sandel's argument here also seems clearly false. In a society of devout voluntarist liberals, each deeply attached to the rights of others to make choices-even bad choices-for themselves, why wouldn't social cooperation and peace be achieved? Is there some instinct of an extraordinarily imperialistic superego that forces us to cram our values down other people's throats, despite our conscious acceptance of their right to choose different lifestyles than our own?

Sandel's second argument is what I shall call the argument from nonneutral application. This argument asserts that even if there were some neutral justification (minimalist or voluntarist) for a right of each of us to decide whether to have an abortion or whether to engage in homosexual sex, this liberty-right would not be neutral in its application to particular decisions, however neutral it may be in its derivation. Some view of the moral merits about such practices must be smuggled in if such a right is to be given concrete application.

This argument too has its analogue in that part of legal philosophy known as the theory of adjudication. It is common to argue that general legal standards are indeterminate in their application to some, many, or perhaps all concrete cases. ${ }^{30}$ Such standards may be vague, ambiguous, or open-textured, and thus require a judge to make some value judgments in applying them. What cannot be accomplished is the exclusion of value judgments in adjudication, an exclusion that some theories of law require.

Sandel's use of this well-worn argument is puzzling. Against minimalist liberalism Sandel has the following to say:

Even given an agreement to bracket controversial moral and religious issues for the sake of social cooperation, it may be controversial what counts as bracketing; and this controversy may require for its solution either a substantive evaluation of the interests at stake, or the autonomous conception of agency that minimalist liberalism resolves to avoid. ${ }^{31}$

Sandel's example of the ambiguity of "bracketing" is provided by the

30. See, e.g., Moore, The Semantics of Judging, 54 S. CAL. L. REv. 151 (1981).

31. Moral Argument, supra note 12, at 532. 
differing views of Justices White and Stevens in Thornburgh v. American College of Obstetricians and Gynecologists. ${ }^{32}$ Justice White urged the Court to bracket the moral issue of abortion by letting the state legislatures decide; Justice Stevens urged the Court to bracket the moral issue by letting each woman decide for herself. "[B]oth ways of bracketing are in principle consistent with minimalist hberalism," Sandel concludes; 33 so deciding between them involves the Court in either a view of the merits about the morality of abortion, or a view about persons and their intrinsic riglits. And "both solutions . . . would deny minimalist hiberalism its minimalism. . ."34

Sandel is here undone by his failure to separate constitutional law from political theory. His ambiguity in what bracketing comes to exists only because he liasn't decided whether the institution asking the question is a court or a legislature. If it is a court, of course there is an ambiguity, because considerations of court function intrude. That is why I urged earlier that our question is one of political theory, asked from the point of view of the legislator. From sucli a point of view there is no ambiguity of "bracketing": To bracket the moral issue of abortion is to let the woman decide for lierself.

Sandel had a better point than his Thornburgh example allowed lim to make. The point sliould lave been that agreements run out in the details that they can govern. It is easy enougli to agree that everyone has a right to free speech, liarder to secure agreement that that means the Nazis can march in Skokie. Sandel's better point would have been to argue that no amount of purely liberal agreeinent about rights at a high level of abstraction will serve the minimalist ends of social cooperation and harmony. Needed is agreement in the details of low tliose rights are to be applied in concrete instances, but only agreement on the morality of practices like abortion allows agreement on concrete applications of an abstract right of liberty (that purports to bracket the moral controversy about abortion).

Sandel comes close to saying this when lie applies the argument from nonneutral application to voluntarist liberalism. One of Sandel's voluntarist liberals, Dworkin, at one time thouglit that liberalism's political inorality could be captured by the riglit of every citizen to equal concern and respect by lier government. ${ }^{35}$ Sandel points out an ambiguity in the quality of respect sucli a riglit guarantees: In the case of homosexuals, is it only the tlim respect given those who act sinfully but within their rights? Or is it the riclier respect possible if one likens lomosexual

\footnotetext{
32. 476 U.S. 747 (1986).

33. Moral Argument, supra note 12, at 533.

34. Id.

35. R. DWORKIN, supra note 25 , at $266-78$.
} 
sex to heterosexual sex, an analogy one can draw only if one thinks both are morally permissible ${ }^{36}$

Sandel worries that if it is only the former respect, then this "leaves wholly unchallenged the adverse views of homosexuality itself."37 Such unchallenged adverse views leave much potential for social disharmony, because voluntarist-based laws allowing homosexual behavior are "unlikely to win for homosexuals more than a thin and fragile toleration."38

As an argument against voluntarist liberalism, this argument is misdirected. The voluntarist is a metaphysician about morality, holding that moral rights exist independent of whether they serve some conflict-minimizing function. How well or poorly such rights serve such a function is, for the voluntarist, irrelevant to their existence. Moreover, the most credible form of voluntarism holds that moral rights are not indeterminate in their content. ${ }^{39}$ Our knowledge of the true nature of the right to equal concern and respect may be (and surely is) incomplete; but the truth about the nature of such a right need not be incomplete for someone with the voluntarist's metaphysical commitments. ${ }^{40}$

Even when construed as an objection only to minimalist liberalism, the argument from nonneutral application is hostage to the unrealistic psychological assumption mentioned before. A society of sincere liberals could easily achieve harmony and cooperation without resolving their first-order differences about the morality of practices like abortion and homosexuality, as long as they strongly believed in the rightness of tolerance, pluralism, and autonomy. To think otherwise is to postulate some instinct of moral imperialism that I don't think is very plausibly an aspect of human nature.

Given the thinness with which Sandel has specified the arguments from nonneutral derivation and from nonneutral application, it has taken some reconstruction to attribute these arguments to him at all. Such arguments cry out for a more complete exposition, and one that makes such arguments generically, and not just as applied to the Supreme Court's treatment of abortion and homosexuality.

My suspicion is that a more complete, more generic exposition of these arguments would reveal their essentially question-begging charac-

36. Moral Argument, supra note 12, at 537.

37. Id.

38. Id.

39. See Moore, Moral Reality, 1982 WIS. L. REv. 1061, 1149-52; Moore, Moral Realism as the Best Explanation of Moral Experience (unpublished manuscript) (Jan. 1989).

40. I explore the compatibility of realist metaphysical commitments about morality, with a right answer thesis about morality, in Moore, Metaphysics, Epistemology, and Legal Theory, $60 \mathrm{~S}$. CAL. L. REV. 453 (1987); and in Moore, The Interpretive Turn in Modern Theory: A Turn For the Worse, 41 Stan. L. REV. 871 (1989). 
ter. Notice that both arguments assume that the morality of liberalism (misleadingly called the morality of right by Sandel) "runs out" in two senses: First, in the sense that justification ultimately is impossible within the confines of such morality; and second, in the sense that application to concrete cases is also impossible within the confines of such morality. Both arguments further assume that the consequentialist morality that Sandel favors (misleadingly called by him the morality of the good) does not run out in either of these ways; that is why the morahty of the good may supplement the liberal's morality of right. Such assumptions support Sandel's thesis that the justice of laws against abortion and homosexual sodomy depend, at least in part, on the moral goodness of those practices only in the Pickwickian sense that they assume it.

Any non-question-begging support for Sandel's thesis must come from arguments different than these. Sandel should give up possibility arguments and confront liberalism on the moral merits. Sandel accuses liberals (and their fellow sophisticates, the majoritarians) of illegitimately trying to keep their conservative opponents off the playing field of firstorder moral disputes. This, liberals do by saying that it is undesirable to incorporate any view of the moral merits of specific practices into political institutions, and that the only political debate to have is about the fair framework in which differing visions of the good life may compete.

Sandel's mode of argument against liberals is subject to the same objection: $\mathrm{He}$ is trying to keep liberals off the second-order playing field where differing visions of fair frameworks may compete. Rather than entering the tourney lists himself, making normative arguments why the liberal vision of fair framework is undesirable, Sandel disdains the tournament entirely as an impossible enterprise. ${ }^{41}$

This would be a good move if Sandel could bring it off, but for the reasons I have discussed he has not done so and probably cannot do so. The reasons why I sympathize with Sandel's thesis thus have nothing to do with Sandel's arguments for it. My own view is that liberalism as Sandel has defined it is undesirable. This stems from an aspect of Sandel's liberalism that I shall call its exclusionary feature. The Sandelian liberal (that is, Sandel's opponent) believes that one category of morality can exclude another category of morality from counting in judging the rightness of political institutions. Specifically, such a liberal believes that the goodness or badness of practices like abortion and homosexuality does not count at all in judging the rightness of political institutions dealing with such behavior; it does not count because it is excluded by moral considerations of fairness. Such fairness operates not only as a first-order reason of morality, giving all rational agents a reason

41. For a similar observation, directed against Critical Legal Studies, see Herzog, As Many As Six Impossible Things Before Breakfast, 75 CaLIF. L. REv. 609 (1987). 
to set up fair institutions, but also as a second-order reason of morality that excludes competing moral reasons from counting. ${ }^{42}$ Morality, on this view, is a hierarchically organized set of reasons, some of which operate as exclusionary and protected reasons. ${ }^{43}$

I have elsewhere dealt at length with this view of morality. ${ }^{44}$ Briefly, the argument against such a view is a moral argument: Nothing that is morally good or bad can be excluded in judging the morality of a political institution without skewing one's judgments about the allthings-considered desirability of that institution. One might think, as I do, that the ideal of autonomy provides a very strong, first-order reason of morality not to regulate a woman's decision whether or not to have an abortion. Such an ideal does not provide a second-order reason that justifies excluding other first-order reasons of morality, such as the reason provided by the wrongness of killing a fetus. The woman's autonomy may outweigh, but it does not exclude, the wrongness of killing a fetus. To hold otherwise, as does the Sandelian liberal, is to invite systematic moral error.

\section{IV}

\section{NON-SANDELIAN LIBERALISM}

The preceding discussion paves the way to glimpsing the possibility of a naive liberalism, one that is not subject to my or Sandel's objections to the sophisticated view. The naive liberal admits that the (im)morality of practices like abortion and homosexuality counts in assessing political/legal institutions dealing with such practices. Such an admission is what makes him "naive" in Sandel's lexicon. What make him a liberal is what else he holds to count in assessing the rightness of laws dealing with homosexuality and abortion; namely the goodness of pluralism, tolerance, and autonomy. This familiar triad of values may be held to be intrinsically good (the analogue of Sandel's voluntarist liberal), or only instrumentally so (the analogue of Sandel's minimalist and utilitarian liberals). In any case, the naive liberal holds that this triad of values has great weight in assessing the rightness of political institutions-indeed, such great weight that the furtherance of these values often outweighs the furtherance of other values, such as the moral badness of abortion or homosexual sodomy, if bad they be. But this triad of values does not have conclusive weight, which is what the exclusionary liberalism Sandel attacks would give it. The three liberal values can be outweighed by the badness of practices whose moral depravity is high.

\footnotetext{
42. For the difference between first-order and second-order moral reasons, see J. RAZ, Practical Reason aNd NoRMS (1976).

43. See J. Raz, The Authority of LAw 16-18 (1979).

44. Moore, Law, Authority, and Razian Reasons, 62 S. CAL. L. REv. (forthcoming 1989).
} 
Sandel might think that this is not liberalism, and of course it isn't if liberals have to be sophisticates. But the naive liberal reaches virtually the same outcomes as the sophisticated liberal, even if his reasoning and supporting justifications are different. That the legislature has no business regulating either abortions or homosexual behavior is an outcome my own view (naive liberalism) easily reaches. Finding such a pattern of outcomes more useful as a classificatory device than the structure of reasons onto which Sandel fastens, I call myself, and this view, liberal. While this may disqualify me from running for president, there is little else to be said against such labeling. 
